\title{
Microbial Metabolism Studies of Cyanthiwigin B and the Synergetic Antibiotic effects
}

\author{
Jiangnan Peng ${ }^{\dagger}$, Noer Kasanah ${ }^{\dagger}$, Charles E. Stanley ${ }^{\dagger}$, Jennifer Chadwick ${ }^{\dagger}$, Frank R. \\ Fronczek ${ }^{\ddagger}$, and Mark T. Hamann ${ }^{{ }^{\prime}}, \dagger$ \\ Department of Pharmacognosy and National Center for Natural Products Research, School of \\ Pharmacy, University of Mississippi, MS 38677, USA, Chemistry Department, Louisiana State \\ University, Baton Rouge, Louisiana 70803-1804
}

\begin{abstract}
Microbial transformation studies of the marine diterpene cyanthiwigin B (1), isolated from the Jamaican sponge Myrmekioderma styx, were accomplished. Two actinomycetes cultures Streptomyces NRRL 5690 and Streptomyces spheroides, significantly metabolized cyanthiwigin B to new metabolites. Streptomyces NRRL 5690 transformed cyanthiwigin B to three new compounds cyanthiwigins $\mathrm{AE}(\mathbf{2}), \mathrm{AF}(\mathbf{3}), \mathrm{AG}(\mathbf{4})$, and the known cyanthiwigin $\mathrm{R}(\mathbf{5})$. S. spheroides transformed cyanthiwigin B to cyanthiwigins S (6), E (7), and AE (2). All microbial metabolized derivatives (2 $\sim 7$ ) of cyanthiwigin B exhibited the ability to increase the antimicrobial activity of curcuphenol, the major antimicrobial sesquiterpene isolated from $M$. styx.
\end{abstract}

Cyanthiwigins are a class of 5,6,7-tricarbocyclic diterpenes, which were first isolated from a Jamaican sponge Epipolasis reiswigi in $1992 .{ }^{1}$ Cyanthiwigin C and two analogous epoxides were reported in the same year from a Venezuelan sponge Myrmekioderma styx. ${ }^{2}$ Since this diterpene class has the same tricarbocyclic skeleton as the cyanthins, metabolites from the bird's nest fungus Cyanthus sp., ${ }^{3}$ they were named cyanthiwigins. In the interest of identifying anticancer and anti-infective leads from Jamaican deep reef invertebrates, we isolated thirty diterpenes, cyanthiwigins A-AD, from the sponge Myrmekioderma styx $, 4,5$ of which cyanthiwigin B (1) is presented in the highest yield. Additionally, cyanthiwigin B has the unique characteristic of increasing the antimicrobial activity of curcuphenol (8), a sesquiterpene isolated from the same sponge. ${ }^{6}$ Recently, total synthesis of cyanthiwigin $U$ was achieved. ${ }^{7}$ Microbial transformations have been shown to be a productive method for the modification of natural products. ${ }^{8}$ In order to improve the synergetic antimicrobial effect, cyanthiwigin B (1) was subjected to a biotransformation study.

Biotransformations of terpenoids have been reported as having particular significance due to their application as fragrances or flavoring agents, their antibacterial, antiviral or cytotoxic activities and their increasing importance as specific pharmacological agents. The ability of microbial transformations to introduce functional groups with regio- and stereo-selectivity remains unrivaled by existing chemical methodologies. ${ }^{9}$ In most cases biotransformation leads to the inactivation of drugs. However the biotransformation can also lead to the generation of a more active or less toxic metabolites. In some instances, biotransformations can produce reactive or toxic intermediates with potential toxicological implications. Hence, an

\footnotetext{
*To whom correspondence should be addressed. Tel.: 662-915-5730. Fax: 662-915-6975. Email: mthamann@olemiss.edu.

$\dagger$ University of Mississippi.

†Louisiana State University.
} 
understanding of the metabolism of new chemical entities is a valuable component of the drug discovery process. ${ }^{10}$

\section{Results and Discussion}

Ten microorganisms were screened for their ability to transform cyanthiwigin B (1) to more active metabolites. Two actinomycetes cultures Streptomyces NRRL 5690 and Streptomyces spheroides, showed significant biocatalysis of cyanthiwigin B and were selected for preparative-scale fermentation. Streptomyces NRRL 5690 was able to transform cyanthiwigin B to cyanthiwigins $\mathrm{AE}(\mathbf{2}, \mathbf{1 3 . 5 \% )}, \mathrm{AF}(\mathbf{3}, 3 \%), \mathrm{AG}(\mathbf{4}, 3 \%)$, and $\mathrm{R}(\mathbf{5}, 2 \%)$. S. spheroides transformed cyanthiwigin to cyanthiwigins $\mathrm{S}(\mathbf{6}, 2 \%), \mathrm{E}(\mathbf{7}, 1 \%)$ and $\mathrm{AE}(\mathbf{2}, 1.5 \%)$.

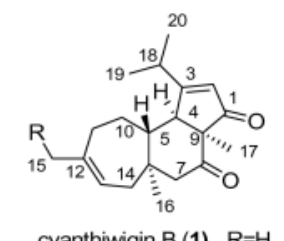

cyanthiwigin $\mathrm{B}$ (1) $\mathrm{R}=\mathrm{H}$ cyanthiwigin $\mathrm{AF}$ (3) $\mathrm{R}=\mathrm{OH}$

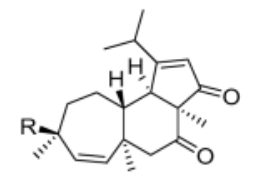

cyanthiwigin $\mathrm{R}(5) \mathrm{R}=\mathrm{OOH}$ cyanthiwigin $\mathrm{S}(6) \mathrm{R}=\mathrm{OH}$

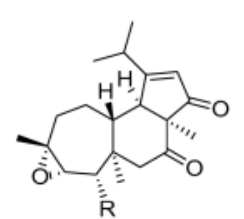

cyanthiwigin $A E$ (2) $\mathrm{R}=\mathrm{H}$ cyanthiwigin $\mathrm{AG}$ (4) $\mathrm{R}=\mathrm{OH}$

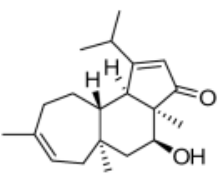

cyanthiwigin $\mathrm{E}$ (7)

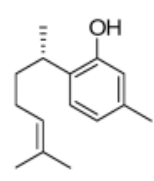

curcuphenol (8)

Cyanthiwigin AE (2) was obtained as a white powder. Its molecular formula was deduced as $\mathrm{C}_{20} \mathrm{H}_{28} \mathrm{O}_{3}$ by high-resolution ESIMS [M+Na] 339.1918 (calcd. 339.1936). The ${ }^{1} \mathrm{H}$ NMR provided characteristic signals of cyanthiwigin type diterpenes, including an olefinic proton at $\delta 5.81(\mathrm{H}-2)$, a methine proton at $\delta 2.73(\mathrm{~d}, J=8.9 \mathrm{~Hz}, \mathrm{H}-4)$, and five methyl protons at $\delta 0.94$ $(\mathrm{s}), 1.16(\mathrm{~s}), 1.22(\mathrm{~s}), 1.19(\mathrm{~d}, J=7.0 \mathrm{~Hz})$, and $1.29(\mathrm{~d}, J=6.5 \mathrm{~Hz})$. In comparison to cyanthiwigin B (1), 2 revealed the absence of carbon signals of the double bound between C-12 and C-13 and new carbon signals at $\delta 60.0$ and 62.3 , which indicated the double bound was converted to an epoxy functionality. The structure was verified by long-range heteronuclear correlations (HMBC) of $\delta 2.03(\mathrm{H}-11), 1.88(\mathrm{H}-14), 1.22(\mathrm{H}-15)$ to $\delta 60.0(\mathrm{C}-12)$ and $62.3(\mathrm{C}-13)$, as well as $\delta 2.84(\mathrm{H}-13)$ to $\delta 41.3(\mathrm{C}-6,14), 60.0(\mathrm{C}-12)$ and $24.5(\mathrm{C}-15)$. The $1 \mathrm{D}$ and 2D NMR data for the remainder of the structure were superimposable with that of cyanthiwigin B (1). The relative stereochemistry of the epoxide group was assigned as $\alpha$ by comparison of the coupling constant and NOE correlations of $\mathrm{H}-13$ with those of cyanthiwigins $\mathrm{H}$ and J. ${ }^{4}$ The signal of $\mathrm{H}-13$ was shown to be a triplet with a small ${ }^{3} J$ coupling constant of $3.6 \mathrm{~Hz}$ for cyanthiwigin $\mathrm{AE}$, which is significantly different as compared to the large ${ }^{3} J$ values of 8.0 and $7.2 \mathrm{~Hz}$ for cyanthiwigins $\mathrm{H}$ and $\mathrm{J}$. In the NOESY spectrum, H-13 ( $\delta 2.84$ ) did not show correlations to $\mathrm{H}-16(\delta 0.94)$, while the NOE correlations between $\mathrm{H}-13$ and $\mathrm{H}-16$ were observed in cyanthiwigins $\mathrm{H}$ and $\mathrm{J} .{ }^{4}$ These indicated the $\alpha$ orientation of the epoxide group of cyanthiwigin $\mathrm{AE}$ rather than the $\beta$ orientation for cyanthiwigins $\mathrm{H}$ and $\mathrm{J}$. To confirm the stereochemistry, crystals of $\mathbf{2}$ were grown in acetone. X-ray diffraction analysis was performed and the crystal structure with relative configuration is shown in Fig. 1.

Cyanthiwigin $\mathrm{AF}(\mathbf{3})$ was also obtained as a white powder. The molecular formula $\mathrm{C}_{20} \mathrm{H}_{28} \mathrm{O}_{3}$ was shown by high-resolution ESIMS [M+Na] 339.1927 (calcd. 339.1936) to have one more oxygen than that of cyanthiwigin B (1). The ${ }^{1} \mathrm{H}$ NMR spectral data of 3 were comparable with that of cyanthiwigin $\mathrm{B}$ with the exception of the loss of a methyl proton signal at $\delta 1.74(\mathrm{H}-15)$ and the addition of an oxygenated methylene proton at $\delta 3.94$, which suggested 
a hydroxyl group at $\mathrm{C}-15$. The ${ }^{13} \mathrm{C}$ NMR spectrum revealed the hydroxymethylene carbon at $\delta 66.8$, which was confirmed to be at C-15 by long-range heteronuclear correlation with $\mathrm{H}-11$ $(\delta 2.19)$.

Cyanthiwigin $\mathrm{AG} \mathrm{(4)} \mathrm{was} \mathrm{isolated} \mathrm{as} \mathrm{a} \mathrm{white} \mathrm{powder} \mathrm{and} \mathrm{its} \mathrm{molecular} \mathrm{formula} \mathrm{C}_{20} \mathrm{H}_{28} \mathrm{O}_{4}$ was obtained from the high-resolution ESIMS [M+Na] 355.1854 (calcd. 355.1885), which has the same degree of unsaturation but two more oxygen atoms than cyanthiwigin B (1). The ${ }^{1} \mathrm{H}$ and ${ }^{13} \mathrm{C}$ NMR data (see Table 1) showed that cyanthiwigin AG is both a hydroxylated and epoxidized derivative of cyanthiwigin B. The epoxide functionality, $\delta_{\mathrm{H}} 3.06, \delta_{\mathrm{C}} 58.8$ and 69.7, was located between C-12 and C-13 based on the HMBC correlations between $\delta 1.24$ (H-15), $2.05(\mathrm{H}-11 \alpha), 1.61(\mathrm{H}-11 \beta)$ and $\mathrm{C}-12$ and $\mathrm{C}-13$. The hydroxyl group was assigned to $\mathrm{C}-14$ by the HMBC correlations from $\delta 0.95(\mathrm{H}-16)$ to $\delta 74.4(\mathrm{C}-14)$ and $\delta 3.66(\mathrm{H}-14)$ to $\delta$ 46.1 (C-6) and 14.2 (C-16). The rest of the molecule remained unmetabolized. A correlation between $\mathrm{H}-14$ and $\mathrm{H}-5$ was observed in the NOESY experiment, indicating that $\mathrm{H}-14$ has the same $\beta$ orientation with $\mathrm{H}-5$. The broad singlet of the H-13 signal suggested a cis axialequatorial relationship of $\mathrm{H}-13$ and $\mathrm{H}-14$. $\mathrm{H}-13$ has NOE correlations with $\mathrm{H}-14$ and $\mathrm{H}-15$, indicating the $\beta$ orientation of $\mathrm{H}-13$ and $\mathrm{CH}_{3}-15$ and the $\alpha$ orientation of the epoxy group.

Compounds 5-7 were identified as cyanthiwigins R, S, and E by comparison of the TLC and NMR data with the authentic samples isolated from the same sample of sponge from which cyanthiwigin B was isolated. ${ }^{4}$ This data suggested that cyanthiwigins R, S, and E, originally isolated from the sponge $M$. styx, maybe metabolites of sponge associated microbes.

All microbial metabolites (2-7) of cyanthiwigin B were tested for their ability to increase the anti-microbial activity of curcuphenol (8) and the results are shown in Table 2. Cyanthiwigins were first tested for the antimicrobial activity, and then mixed with curcuphenol followed by the repeat testing for antimicrobial activity. Due to the limited amount of cyanthiwigins AF (3) and AG (4), they were directly mixed with curcuphenol. Curcuphenol exhibited antimicrobial activity with $\mathrm{IC}_{50} 15 \mu \mathrm{g} / \mathrm{mL}$ against Cryptococcus neoformans and $\mathrm{IC}_{50}>15 \mu \mathrm{g} / \mathrm{mL}$ against Candida albicans, Staphylococcus aureus, and methicillin-resistant $S$. aureus (MRS). Cyanthiwigins B (1), AE (2), R (5), S (6), and E (7) were not active against all the tested microbes when assayed alone. All mixtures exhibited better activity than curcuphenol, indicating the ability of cyanthiwigins to increase the antimicrobial activity. Cyanthiwigin AE (2) and AF (3) are more potent than cyanthiwigin B (1), E (7), and S (6), and cyanthiwigin R (5) has the least potency.

\section{Experimental Section}

\section{General Experiment Procedures}

Optical rotations were measured with a JASCO DIP-370 digital polarimeter. IR and UV spectra were obtained using an AATI Mattson Genesis Series FTIR and a Hewlett Packard 8452A diode array spectrometer. NMR spectra were measured on Bruker Avance DRX-400. ${ }^{1} \mathrm{H}$ and ${ }^{13} \mathrm{C}$-NMR spectra were measured and reported in ppm by using the residual solvent peak as an internal standard (acetone-d6, $\delta 2.05$ for proton, $\delta 206.7$ for carbon). ESI-FTMS analyses were measured on a Bruker-Magnex BioAPEX 30es ion cyclotron HR-FT spectrometry by direct injection into an electrospray interface. HPLC was carried out on a Waters 510 model system and a dual wavelength detector.

\section{X-ray Analysis}

The crystal was colorless orthorhombic, space group $P 2{ }_{1} 2_{1} 2_{1}$ with cell dimensions $a=8.474$ (3) $\AA, b=10.392$ (3) $\AA, c=19.749$ (8) $\AA, V=1739.1$ (11) $\AA^{3}, Z=1, D_{x}=1.208 \mathrm{Mgm}^{-3}$. Intensity data for cyanthiwigin $\mathrm{AE}(\mathbf{2})^{11}$ were collected at $102 \mathrm{~K}$ on a Nonius KappaCCD (with Oxford Cryostream) diffractometer equipped with $\operatorname{Mo} K \alpha(\lambda=0.71073 \AA$ ) radiation 
using $\omega-2 \theta$ scan, $2 \theta$ range $2.5-27.5^{\circ} .2266$ independent reflections were obtained with 1871 reflections having $I>2 \sigma(I)$. Data reduction was by DENZOSMN ${ }^{11}$ and SCALEPAK. ${ }^{12}$ The structure was solved by direct methods and refined by full-matrix least-squares using SHELXL. 13 All non-hydrogen atoms were refined anisotropically. Hydrogen atoms were constrained in calculated positions. Atomic coordinates, crystal data, final $R$ values, and other details are included in Tables 3, 4, and 5, Supporting Information.

\section{Material}

Cyanthiwigin B (1) was isolated from Myrmekioderma styx and its structure was determined by spectral analysis as previously reported. ${ }^{4}$

\section{Microorganisms}

Streptomyces NRRL 5690, S. argenteolus. S. seokies, S. spheroides, Saccahromyces cerevisiae, Penicillium sp, Aspergillus sp, Geotrichum sp, Fusarium solani and $F$. oxysporium. All microorganisms were obtained from the collection at the Department of Pharmacognosy, The University of Mississippi.

\section{Microbial Metabolism}

All microorganisms were subjected to screening for their ability to transform cyanthiwigin B by inoculating them in $25 \mathrm{~mL}$ media that contain $3 \mathrm{mg}$ cyanthiwigin $\mathrm{B}$. The cultures were shaken in an incubator shaker at $200 \mathrm{rpm}, 28^{\circ}$. The biotransformation process was monitored at 3, 5, 10, 14 and 18 days using TLC. Streptomyces NRRL 5690 was able to metabolize the compound in 5 days while $S$. spheroides metabolized the compounds from 5 to 10 days. The rest of the microorganisms did not metabolize the compound until the 18 days fermentation. For scaling-up Streptomyces NRRL 5690 and S. spheroides were grown in $100 \mathrm{~mL}$ media containing $20 \mathrm{mg}$ of cyanthiwigin B. The cultures were shaken in an incubator shaker at 200 $\mathrm{rpm}, 28^{\circ}$. The fermentation was stopped after 5 days for Streptomyces NRRL 5690 and 10 days for $S$. spheroides.

\section{Isolation}

The whole culture of Streptomyces NRRL 5690 was extracted with EtOAc. The extract (15.9 $\mathrm{mg}$ ) was subjected to HPLC using a Phenomenex Luna C8 column, $5 \mu \mathrm{m}, 250 \times 21.5 \mathrm{~mm}$, eluted with a gradient of 50\% acetonitrile in $\mathrm{H}_{2} \mathrm{O}$ to $100 \%$ acetonitrile over $50 \mathrm{~min}$ at a flow rate of $6 \mathrm{~mL} / \mathrm{min}$ and a detector wavelength of $254 \mathrm{~nm}$. Fraction 9 and 13 gave pure cyanthiwigin AE $(\mathbf{2}, 2.7 \mathrm{mg})$ and $\mathrm{R}(\mathbf{5}, 0.4 \mathrm{mg})$, respectively. Fraction 5 was separated by silica gel preparative thin layer chromatography using hexane-EtOAc $1: 1$ as a developing solvent to yield cyanthiwigin $\mathrm{AF}(\mathbf{3}, 0.6 \mathrm{mg})$ and $\mathrm{AG}(\mathbf{4}, 0.6 \mathrm{mg})$.

The whole extract of Streptomyces spheroides was extracted with EtOAc. The extract (13.2 $\mathrm{mg}$ ) was chromatographed using an HPLC column using the same condition as above. Fraction 9 and 17 gave cyanthiwigins $S(6,0.4 \mathrm{mg})$ and $\mathrm{E}(\mathbf{7}, 0.2 \mathrm{mg})$. Fraction 13 yielded cyanthiwigin $\mathrm{AE}(\mathbf{2}, 0.3 \mathrm{mg})$ after purification by PTLC (silica gel, hexanes-EtOAc 1:1).

\section{Cyanthiwigin AE (2)}

Colorless crystal; $[\alpha]^{26} \mathrm{D}-285$ (c 0.09, MeOH); UV (MeOH) $\lambda_{\max }(\log \varepsilon) 236$ (4.15) nm; IR (film) $v_{\max } 2971,1725,1689,1605,1433,1383,1261,1171,870 \mathrm{~cm}^{-1}$; HRESIMS m/ $z 339.1918[\mathrm{M}+\mathrm{Na}]^{+}$(calcd for $\mathrm{C}_{20} \mathrm{H}_{28} \mathrm{O}_{3} \mathrm{Na} 339.1936$ ), $655.3964[2 \mathrm{M}+\mathrm{Na}]^{+}$(calcd for $\mathrm{C}_{40} \mathrm{H}_{56} \mathrm{O}_{6} \mathrm{Na}$ 655.3975). 


\section{Cyanthiwigin AF (3)}

white powder; $[\alpha]^{26}{ }_{\mathrm{D}}-284(c 0.06, \mathrm{MeOH}) ; \mathrm{UV}(\mathrm{MeOH}) \lambda_{\max }(\log \varepsilon) 236(4.00) \mathrm{nm}$; IR (film) $v_{\max } 3448,2963,1724,1687,1603,1455,1384,1260,1086,868 \mathrm{~cm}^{-1}$; HRESIMS $\mathrm{m} / z$ $339.1927[\mathrm{M}+\mathrm{Na}]^{+}$(calcd for $\left.\mathrm{C}_{20} \mathrm{H}_{28} \mathrm{O}_{3} \mathrm{Na} 339.1936\right), 655.3981[2 \mathrm{M}+\mathrm{Na}]^{+}$(calcd for $\mathrm{C}_{40} \mathrm{H}_{56} \mathrm{O}_{6} \mathrm{Na}$ 655.3975).

\section{Cyanthiwigin AG (4)}

white powder; $[\alpha]^{26}{ }_{\mathrm{D}}-145(c 0.06, \mathrm{MeOH}) ; \mathrm{UV}(\mathrm{MeOH}) \lambda_{\max }(\log \varepsilon) 236(3.86) \mathrm{nm}$; IR (film) $v_{\max } 3436,2964,1725,1691,1605,1454,1259,1006,826 \mathrm{~cm}^{-1}$; HRESIMS m/z 355.1854 [M $+\mathrm{Na}]^{+}$(calcd for $\mathrm{C}_{20} \mathrm{H}_{28} \mathrm{O}_{4} \mathrm{Na} 355.1885$ ), $687.3824[2 \mathrm{M}+\mathrm{Na}]^{+}\left(\right.$calcd for $\mathrm{C}_{40} \mathrm{H}_{56} \mathrm{O}_{8} \mathrm{Na}$ 687.3872).

\section{Supplementary Material}

Refer to Web version on PubMed Central for supplementary material.

\section{Acknowledgements}

We gratefully acknowledge S. C. Sanders and B. G. Smiley from the National Center for Natural Products Research for antimicrobial testing. This work was supported by NIH grant (1R01A136596) and PharmaMar.

\section{References and Notes}

1. Green D, Goldberg I, Stein Z, Ilan M, Kashman Y. Nat Prod Lett 1992;1:193-199.

2. Sennett SH, Pomponi SA, Wright AE. J Nat Prod 1992;55:1421-1429. [PubMed: 1453179]

3. Ayer WA, Taube H. Can J Chem 1973;51:3842-3853.

4. Peng J, Walsh K, Weedman V, Braude IA, Kelly M, Hamann MT. Tetrahedron 2002;58:7809-7819.

5. Peng J, Avery MA, Hamann MT. Org Lett 2003;5:4575-4578. [PubMed: 14627387]

6. Peng J, Franzblau SG, Zhang F, Hamann MT. Tetrahedron Lett 2002;43:9699-9702.

7. Pfeiffer MWB, Phillips AJ. J Am Chem Soc 2005;127:5334-5335. [PubMed: 15826167]

8. El Sayed KA, Yousaf M, Hamann MT, Avery MA, Kelly M, Wipf P. J Nat Prod 2002;65:1547-1553. [PubMed: 12444675]

9. Azerad, R. Stereoselective Biocatalysis. Patel, RN., editor. Marcel Dekker, Inc; New York: 2000. p. 153-180.

10. Kumar GN, Surapaneni S. Med Res Review 2001;21:397-411.

11. A full list of crystallographic data and parameters is deposited at the Cambridge Crystallographic Data Centre, 12 Union Rd., Cambridge CB2 1EZ, Cambridge, UK

12. Otwinowski Z, Minor W. Methods Enzymol 1997;276:307-326.

13. Sheldrick, GM. SHELXL97. Program for the Refinement of Crystal Structures. University of Gottingen; Germany: 1997. 


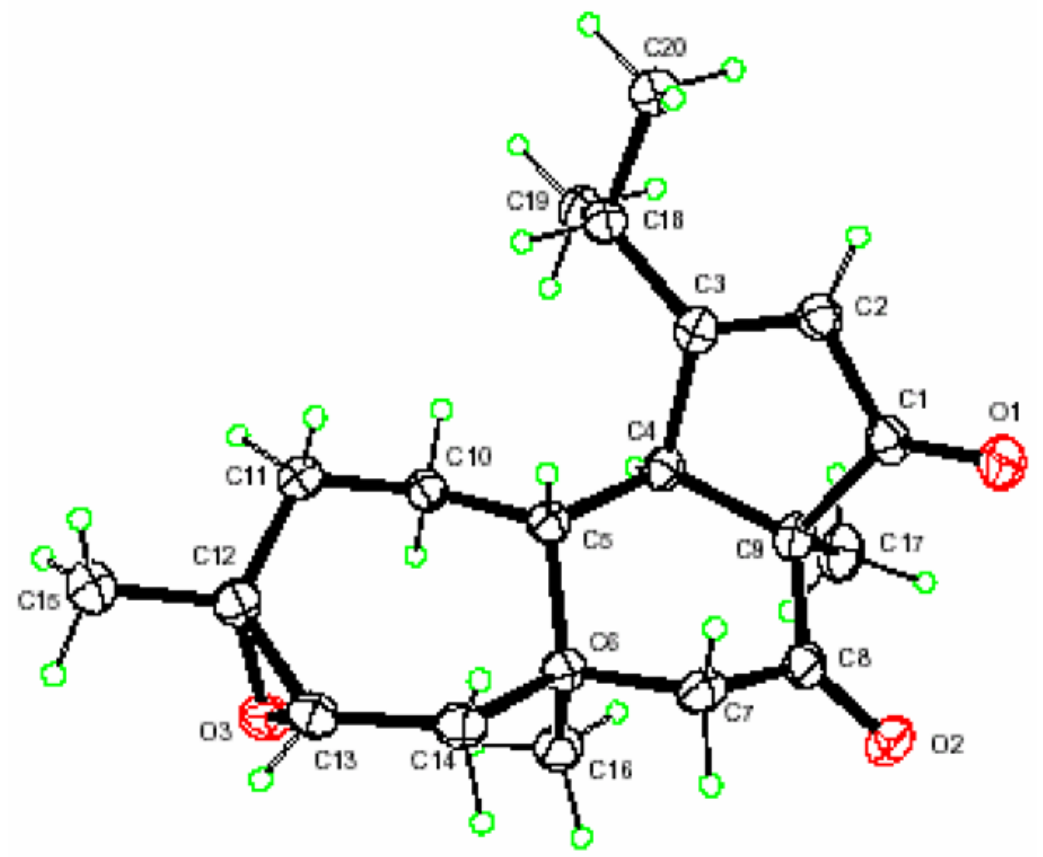

Figure 1.

$\mathrm{X}$-ray structure of $\mathbf{2}$ 


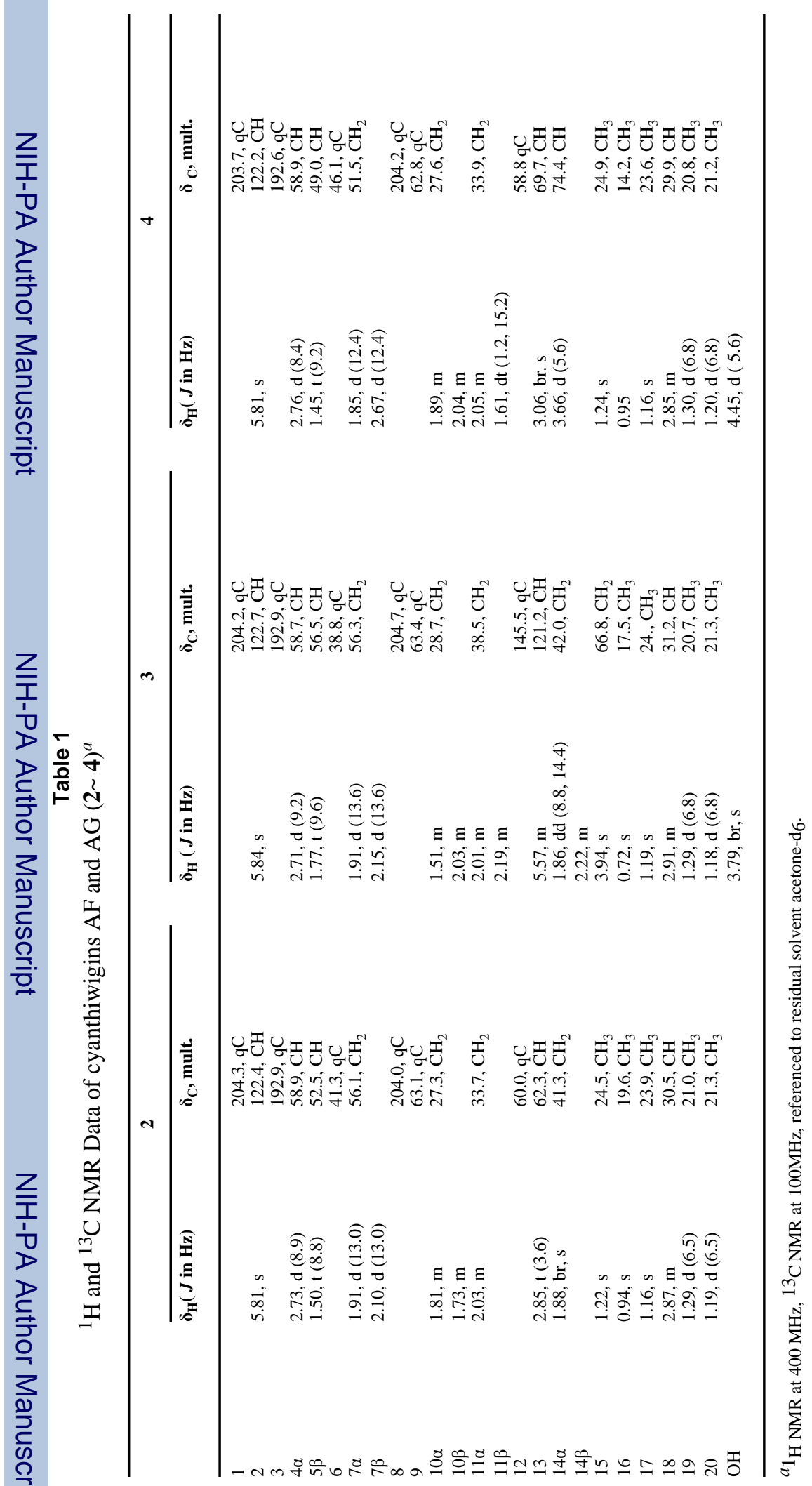


Antimicrobial Activity

Table 2

\begin{tabular}{|c|c|c|c|c|}
\hline & \multicolumn{2}{|c|}{ Antifungal $\mathrm{IC}_{50}(\mu \mathrm{g} / \mathrm{mL})$} & \multicolumn{2}{|c|}{ Antibacterial IC $_{50}(\mu \mathrm{g} / \mathrm{mL})$} \\
\hline & Candida albicans & $\begin{array}{l}\text { Cryptococcus } \\
\text { neoformans }\end{array}$ & Staphylococcus aureus & MRS $^{\mathrm{a}}$ \\
\hline curcuphenol & $>15$ & 15 & $>15$ & $>15$ \\
\hline cyanthiwigin B & NA & NA & NA & NA \\
\hline $\begin{array}{l}\text { cyanthiwigin } B+\text { curcuphenol } \\
1.1: 1.8\end{array}$ & $>15$ & 6.0 & 6.5 & 7.0 \\
\hline $\begin{array}{l}\text { cyanthiwigin E } \\
\text { cyantion }\end{array}$ & NA & NA & NA & NA \\
\hline $\begin{array}{l}\text { cyanthiwigin E+ curcuphenol } \\
0.7: 1.7\end{array}$ & $>15$ & 6.0 & 6.5 & 6.5 \\
\hline cyanthiwigin $\mathrm{R}$ & NA & NA & NA & NA \\
\hline $\begin{array}{l}\text { cyanthiwigin R+ curcuphenol } \\
1.0: 1.8\end{array}$ & $>15$ & 10 & $>15$ & $>15$ \\
\hline cyanthiwigin $S$ & NA & NA & NA & NA \\
\hline $\begin{array}{l}\text { cyanthiwigin S+ curcuphenol } \\
0.7: 1.8\end{array}$ & 15 & 6.5 & 8.0 & 7.5 \\
\hline cyanthiwigin $\mathrm{AE}$ & NA & NA & NA & NA \\
\hline $\begin{array}{l}\text { cyanthiwigin AE+ curcuphenol } \\
0.6: 1.8\end{array}$ & 15 & 6.0 & 6.5 & 6.5 \\
\hline $\begin{array}{l}\text { cyanthiwigin } \mathrm{AF}+\text { curcuphenol } \\
0.5: 1.8\end{array}$ & 15 & 5.0 & 6.5 & 6.0 \\
\hline $\begin{array}{l}\text { cyanthiwigin AG+ curcuphenol } \\
0.5: 1.8\end{array}$ & $>15$ & 7.5 & 8.5 & 9.5 \\
\hline
\end{tabular}

MRS= methicillin-resistant Staphylococcus aureus.

IC50 values for curcuphenol and cyanthiwigin mixtures were calculated based on the mass of curcuphenol. 